\title{
Trapetum natantis Müller et Görs 1960 in hydromeliorative facilities in Serbia
}

\author{
Dejana Džigurski*, Branka Ljevnaić-Mašić, Ljiljana Nikolić
}

Faculty of Agriculture, University of Novi Sad, Trg. D. Obradovića 8, Novi Sad, Serbia

\section{Abstract}

Trapa natans is one of the very few plants that generate so many contrasting views: it is highly endangered in Europe, invasive in North America and Australia, yet highly valued in India and China due to its nutritional and medical properties. Its endangered status in most of the Europe has prompted significant conservation efforts aimed at retention and expansion of its population. T. natans is currently on the red list of many European countries and is included under "Appendix I" of the "Convention on the conservation of European wildlife and natural habitats" (Bern Convention) and IPA list (IPA criterion A, threatened species). The unusual circumstances, i.e. endangered status of T. natans in the region on one hand and its expansion in Serbia on the other, are the reason behind this research that aims to present the distribution, floristic composition and ecological conditions of ass. Trapetum natantis stands in hydromeliorative facilities (Serbia), comprised of 28 hydrophytes. In the analyzed stands, based on the long-term phytocenological studies, we have singled out four floristic and ecological groups: the stands in which T. natans predominates, the stands with Ceratophyllum demersum, the stands with lemnids plants (Lemna minor, L. gibba, Spirodela polyrrhiza) and Salvinia natans and the stands with Hydrocharis morsus-ranae. In the researched localities, the differentiation of ass. Trapetum natantis stands is predetermined by the phosphorus and nitrate content, as well as $\mathrm{pH}$ and $\mathrm{BOD}_{5}$ levels.

Keywords: Trapa natans, hydrophytes, the IUCN red list, endangered species, properties of water, Serbia

\section{Introduction}

The issue of species classified as endangered in one region, yet invasive in another, is becoming increasingly complex and important. This is also the case with the hydrophyte Trapa natans, which is one of a very few plants that generate so many contrasting views: it is highly endangered in Europe, invasive in North America and Australia, yet highly valued in India and China due to its nutritional and medical properties [1].

The native area of T. natans is from Western Europe and Africa to northeast Asia including eastern Russia, China, and Southeast Asia, through to Indonesia [2,3]. It is a rare plant in Europe and the subject of conservation efforts to preserve and restore populations. According to the IUCN [4] T. natans is on the regional red list in: Black Sea Region (vulnerable), Bulgaria (endangered), Carpathian Mountains (endangered), Czech Republic (critically endangered), Germany (endangered - level 2), Russia (near threatened), Slovakia (vulnerable), Spain (extinct), Sweden (extinct), Switzerland (critically endangered), Turkey (vulnerable), Ukraine (endangered), France (protected

* Corresponding author. Email: dejana@polj.uns.ac.rs

Handling Editor: Aleksandra Samecka-Cymerman

This is an Open Access digital version of the article distributed under the terms of the Creative Commons Attribution 3.0 License (creativecommons.org/licenses/by/3.0/), which permits redistribution, commercial and non-commercial, provided that the article is properly cited. at regional level), Hungary (protected but not endangered) and Greece (only two populations identified). Due to its endangered status in Montenegro, T. natans has been placed under protection [5]. Ciocârlan [6] emphasizes that, in Romania, this species, which was previously cited as common in literature, has now become extremely rare and that it has even ceased to exist in some lakes. This author characterizes Trapa natans as endangered species, which needs the protection in the Danube Delta region. Moreover, T. natans is included under "Appendix I" of the "Convention on the conservation of European wildlife and natural habitats" (Bern Convention) and IPA list (IPA criterion A, threatened species). Intensive urbanization, water pollution with industrial waste and sewage are cited as the main reasons for the decline of its population $[1,4]$.

T. natans was first introduced to North America and Australia, where it is currently widely dispersed and considered invasive $[2,4,7,8]$. Moreover, it has been characterized by the Global Invasive Species Program of the World Conservation Union as an invasive plant of global significance [9]. Serious concern regarding invasive species has thus become the focus of many scientific studies, which resulted in the rapid development of invasive ecology, but also in the confusion in the use of the terminology. Invasive plants are a subset of naturalized plants that produce reproductive offspring, often in very large numbers, at considerable distances from the parent plants, and thus have the potential to spread over a large area [10]. Aquatic macrophytes can be very dangerous invasive weeds $[7,8,11,12]$. The short life cycle, rapid growth, the selective expression of allelopathic effects on certain native plant communities, high phenotypic plasticity and flexibility of natural resource use, i.e. highly effective physiological and reproductive capacities give 
priority invasive species in relation to native plants [12-15]. Presence of invasive species, eutrophication, climate changes, etc. effect further ecological pressure on the already unbalanced aquatic ecosystems [16-18].

The aim of this paper is to present the distribution, floristic composition and ecological conditions of ass. Trapetum natantis stands in the Hydrosystem Danube-Tisza-Danube (Hs DTD) in Serbia, as well as its differentiation into groups. The study results will fill the gaps in the data pertaining to the Trapa natans spatial distribution and ecology in this part of Europe, bearing in mind a rather complex situation, namely the endangered status in most of the neighboring countries and the population expansion in Serbia.

\section{Material and methods}

Long-term studies of aquatic vegetation of MCN Hs DTD in Vojvodina Province (Serbia) were conducted in the vegetative period between 2003 and 2009, by applying the Braun-Blanquet method [19]. Plant species were determined by Josifović [20], Sarić [21], Tutin et al. [22,23], Felföldy [24] and Jávorka and Csapody [25]. The abundance of each species within the relevé area was according to Braun-Blanquet scale in which: “+” = a few scattered specimens, $1=1-10 \%$ coverage, $2=10-25 \%$ coverage, $3=25-50 \%$ coverage, $4=50-75 \%$ coverage, $5=75-100 \%$ coverage. All the relevés recorded in the investigated phytocoenoses were aggregated in one synoptic phytosociological table that shows the presence degree (\%) and the abundance and coverage (from + to 5). Only stands with at least the minimum area recommended for these types of vegetation were recorded $\left(>5 \mathrm{~m}^{2}\right)$. All the relevés were stored using the TURBOVEG database [26] and processed by JUICE software [27].

In the study period, the water samples were collected three times a year, during the vegetative period (May-August), 30 $\mathrm{cm}$ from water surface, on the canal sections where existence of ass. Trapetum natantis stands were previously ascertained. Basic physical and chemical properties of water were determined according to standard methods [28]. The following parameters were monitored: temperature, $\mathrm{pH}$ value, total alkalinity, chemical $\left(\mathrm{COD}-\mathrm{MnO}_{4}\right)$ and biological $\left(\mathrm{BOD}_{5}\right)$ oxygen demands and nutrient contents (ammonium $\mathrm{NH}_{4}^{+}, \mathrm{NO}_{3}^{-}, \mathrm{NO}_{2}^{-}, \mathrm{PO}_{4}{ }^{3-}$ and total phosphorus).

The water chemical analysis data pertaining to the aforementioned parameters was processed using STATISTICA 7.0 software [29]. The statistical significance of the differences amongst individual groups of the studied phytocenosis, in terms of analyzed water parameters, was established by applying $t$-test.

\section{Studied region}

Hydrosystem Danube-Tisza-Danube (Hs DTD) is a central part of the Rhine-Main-Danube navigational route and one of the largest hydrosystems in Europe. Hs DTD is located in the Vojvodina Province, Serbia ( $44^{\circ} 39^{\prime} 15.04^{\prime \prime}$ and $46^{\circ} 10^{\prime} 11.32^{\prime \prime}$ north latitude to the $18^{\circ} 50^{\prime} 15.00^{\prime \prime}$ and $21^{\circ} 33^{\prime} 27.82^{\prime \prime}$ north longitude). It is an anthropogenic hydrosystem that links 80 towns and villages in the Vojvodina Province, enables drainage of excess water and irrigation of agricultural land, provides water supply to inhabited regions, industry and fish ponds, facilitates drainage of wastewater, enables navigation and is an important resource for recreation, sport and tourism. The total length of Hs DTD (19 canals) is $930 \mathrm{~km}$, of which $600 \mathrm{~km}$ can be used by water traffic (Fig. 1). There are 23 sluices on the main canal network of the Danube-Tisa-Danube Hydrosystem. Sluices were built as independent structures or together with locks within a hydro-knot. The task of a sluice is to regulate the water level in the canal.

Vojvodina is characterized by moderate continental climate. The average annual temperature in this region is $11.0^{\circ} \mathrm{C}$, with the mean annual temperature gradient increasing from the northwest $\left(10.7^{\circ} \mathrm{C}\right)$ to southeast $\left(11.7^{\circ} \mathrm{C}\right)$. In Vojvodina, summers are warm (with average temperatures in the $21-23^{\circ} \mathrm{C}$ range), winters cold (an average of $2^{\circ} \mathrm{C}$ ), and spring and fall rather short $[30,31]$.

\section{Results}

Ass. Trapetum natantis stands are common floating cover on Hs DTD sections in Vojvodina Province. In the studied

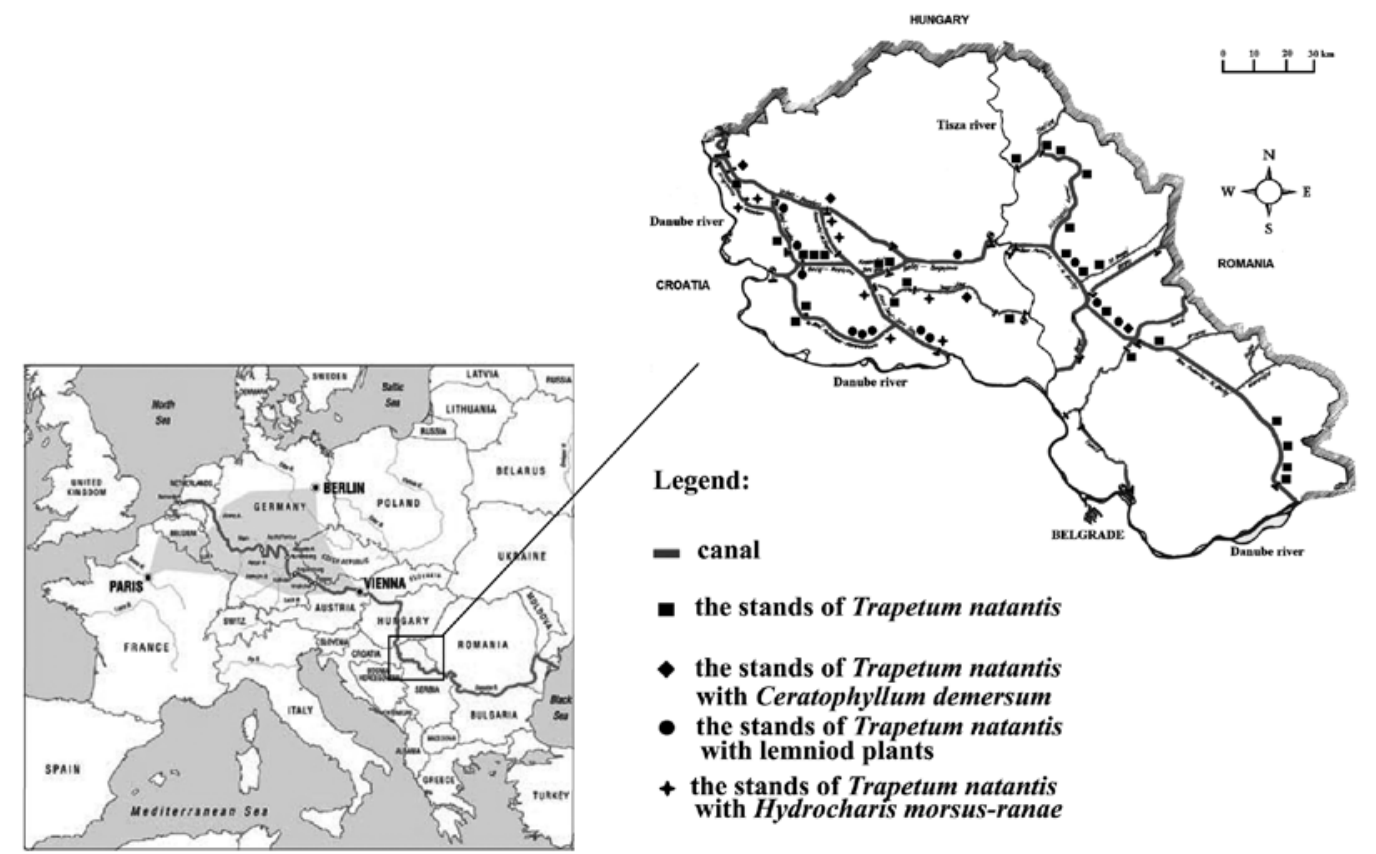

Fig. 1 Distribution of studied phytocoenoses of Trapetum natantis on MCN Hs DTD in Vojvodina Province. 
ecosystem, the stands are mostly developed in the more stagnant and protected parts of the canal, but also in the vicinity of sluices and sections characterized by frequent water level fluctuations.

In the deeper hydroecosystem sections (ca. $3 \mathrm{~m}$ ), where it does not compete with other floating plants, Trapa natans dominates and forms well-developed, abundant and vital individual belt. In shallower hydroecosystem sections (up to $2.5 \mathrm{~m}$ ), stands form mosaic-like floating belt with stands of communities Nymphaeetum albo-luteae Nowinski 1928, Hydrocharidetum morsus-ranae van Langendonck 1935, Salvinio-Spirodeletum polyrrhizae Slavnić 1956 and Lemno-Spirodeletum W. Koch et Tx. ex Oberd 1957. At these depths, water lilies have biological advantage, and are thus gradually replacing water chestnut. Moreover, as the large water lily leaves develop before water chestnut, reducing light intensity under the water surface, the development of T. natans, i.e. its transition from heterotrophic to autotrophic phase, is hindered [32].

The floristic composition of the ass. Trapetum natantis stands consists of 28 species (Tab. 1). The overall coverage of the plant material ranges between 70 and $100 \%$. In the analyzed stands, based on the long-term phytocenological studies, we have singled out four floristic and ecological groups (Tab. 1, Fig. 1):

(i) I group: In most reléves a dominant role has edificator T. natans (group No. 1 in Tab. 1). This group is the richest with species (26 species). Small values of other floating plants in the stands (Nuphar lutea, Nymphea alba, etc.) are understandable due to competition for the same habitat. Unfavorable light regime, caused by large rosettes of T. natans, disables the development of large-scale submerged plants. The stands are developed in the water of (0.3) 2-3 m depth. The stands are rarely developed directly by emergent vegetation $(0.3-0.5 \mathrm{~m})$ and in relevés are also present emergent plants (Glyceria maxima, Sagittaria sagittifolia, Butomus umbellatus, Carex pseudocyperus, Iris pseudacorus).

(ii) II group: the stands with Ceratophyllum demersum L. (group No. 2 in Tab. 1), forms rich submerged layer. Floristic composition includes 16 hydrophytes. In addition to C. demersum, owing to their significant presence, Vallisneria spiralis and Myriophyllum spicatum also contribute to the marked doublelayered stand character. The stands are developed in the water of 1.5-3 m depth.

(iii) III group: the stands with lemnids plants (Lemna minor, L. gibba L., Spirodela polyrrhiza) and Salvinia natans (group No. 3 in Tab. 1). These stands are much poorer with species (12 species). In the shallower parts of hydroecosystem, between the T. natans rosettes, also lemnids plants ( $L$. minor, $L$. gibba, S. polyrrhiza) and S. natans have found suitable conditions for their growth. The stands of small size are also present in deeper water.

(iv) IV group: the stands with Hydrocharis morsus-ranae (group No. 4 in Tab. 1). The stands belonging to this group include 11 species. Massively developed hydrophytes T. natans and $H$. morsus-ranae, as well as L. minor, S. polyrriza and $S$. natans - characterized by small number and scarce coverage, enable the development of a modest layer of submerged plants (C. demersum, M. spicatum, V. spiralis, Potamogeton pectinatus, P. perfoliatus and Elodea canadensis). The optimal development of the stands in this group is achieved at shallower water depths of $0.5-1.5 \mathrm{~m}$.

In the investigated area, in the ecological series towards the middle of the canal, the following submerged association stands are linked to the ass. Trapetum natantis floating stands:
Tab. 1 Synoptic table of the ass. Trapetum natantis in MCN Hs DTD in Vojvodina Province, with percentage frequency and cover range.

\begin{tabular}{|c|c|c|c|c|}
\hline Group No. & 1 & 2 & 3 & 4 \\
\hline No. of relevés & 22 & 11 & 7 & 9 \\
\hline Trapa natans $\mathrm{L}$. & $100^{3-5}$ & $100^{3-5}$ & $100^{3-5}$ & $100^{3-4}$ \\
\hline Ceratophyllum demersum $\mathrm{L}$. & $73^{+-1}$ & $100^{2}$ & $86^{+-2}$ & $78^{+-1}$ \\
\hline Lemna minor $\mathrm{L}$. & $68^{+-1}$ & $18^{+}$ & $100^{+-3}$ & $11^{+}$ \\
\hline Spirodela polyrrhiza (L.) Schleid. & $86^{+-1}$ & $36^{+-2}$ & $86^{+-1}$ & $67^{+-1}$ \\
\hline Salvinia natans (L.) Allioni & $55^{+-1}$ & $73^{+-1}$ & $43^{1}$ & $11^{1}$ \\
\hline Lemna gibba $\mathrm{L}$. & $18^{+}$ & . & $86^{+-2}$ & . \\
\hline Hydrocharis morsus-ranae $\mathrm{L}$. & $23^{+}$ & $64^{+-1}$ & $14^{1}$ & $100^{1-2}$ \\
\hline Myriophyllum spicatum L. & $32^{+}$ & $64^{+-1}$ & . & $56^{+-1}$ \\
\hline Vallisneria spiralis L. & $14^{+}$ & $45^{+-1}$ & . & $56^{+-2}$ \\
\hline Potamogeton fluitans Roth. & $14^{+}$ & . & $71^{+}$ & . \\
\hline Nuphar luteum (L.) Sm. & $14^{+-1}$ & $18^{+-1}$ & $29^{+}$ & . \\
\hline Potamogeton pectinatus $\mathrm{L}$. & $14^{+-1}$ & . & $43^{1}$ & $11^{+}$ \\
\hline Potamogeton crispus L. & $14^{+-} 1$ & $9^{+}$ & $43^{+}$ & . \\
\hline Elodea canadensis Rich & $9^{+-2}$ & $9^{+}$ & $29^{+}$ & $11^{+}$ \\
\hline Najas marina L. & $23^{+-1}$ & . & . & . \\
\hline Sagittaria sagittifolia $\mathrm{L}$. & $9^{+}$ & $18^{+}$ & . & . \\
\hline Potamogeton perfoliatus L. & . & $18^{+-1}$ & . & $11^{+}$ \\
\hline Nymphaea alba L. & $9^{+}$ & $9^{+}$ & . & . \\
\hline Glyceria maxima (Hartm.) Holm. & $14^{+-1}$ & . & . & . \\
\hline Lemna trisulca $\mathrm{L}$. & $5^{+}$ & $9^{+}$ & . & . \\
\hline Nymphoides flava Hill. & $9^{1}$ & . & . & \\
\hline Polygonum amphibium $\mathrm{L}$. & . & $9^{+}$ & . & . \\
\hline Butomus umbellatus $\mathrm{L}$. & $5^{+}$ & . & . & . \\
\hline Azolla filiculoides Lam. & $5^{1}$ & . & . & . \\
\hline Elodea nuttallii (Planch.) H. St. John & $5^{+}$ & . & . & . \\
\hline Potamogeton lucens L. & $5^{+}$ & . & . & . \\
\hline Iris pseudacorus L. & $5^{+}$ & . & . & . \\
\hline Carex pseudocyperus $\mathrm{L}$. & $5^{+}$ & . & . & . \\
\hline
\end{tabular}

Coordinates of the localities: $45.457767^{\circ}, 19.884465^{\circ} ; 45.456455^{\circ}$, $19.796696^{\circ}$; $45.455461^{\circ}, 19.553529^{\circ} ; 45.445441^{\circ}, 19.558876^{\circ}$; $45.429498^{\circ}, 19.566904^{\circ} ; 45.694970^{\circ}, 19.318536^{\circ} ; 45.667509^{\circ}$, $19.327464^{\circ} ; 45.839332^{\circ}, 18.926623^{\circ} ; 45.821960^{\circ}, 18.931192^{\circ}$; $45.704637^{\circ}, 19.300314^{\circ} ; 45.696344^{\circ}, 19.317894^{\circ} ; 45.844361^{\circ}$, $18.925317^{\circ} ; 45.823331^{\circ}, 18.930538^{\circ} ; 45.534823^{\circ}, 19.230637^{\circ}$; $45.826998^{\circ}, 18.896484^{\circ} ; 45.535681^{\circ}, 19.248885^{\circ} ; 45.536475^{\circ}$, $19.284725^{\circ} ; 45.826540^{\circ}, 18.903033^{\circ} ; 45.536058^{\circ}, 19.272995^{\circ}$; $45.506377^{\circ}, 19.578820^{\circ} ; 45.506362^{\circ}, 19.578814^{\circ} ; 45.541957^{\circ}$, $19.903269^{\circ} ; 45.383465^{\circ}, 19.245951^{\circ} ; 45.427664^{\circ}, 19.207865^{\circ}$; $45.410978^{\circ}, 19.218172^{\circ} ; 45.826998^{\circ}, 18.896484^{\circ} ; 45.826163^{\circ}$, $20.188199^{\circ} ; 45.634739^{\circ}, 20.307567^{\circ} ; 45.317132^{\circ}, 20.636822^{\circ}$; $45.307942^{\circ}, 20.654939^{\circ} ; 45.299267^{\circ}, 20.650357^{\circ} ; 45.282587^{\circ}$, $20.726126^{\circ} ; 45.072270^{\circ}, 21.193362^{\circ} ; 44.989037^{\circ}, 21.278883^{\circ}$; $44.890659^{\circ}, 21.259835^{\circ} ; 45.550631^{\circ}, 20.330467^{\circ} ; 45.478842^{\circ}$, $20.420946^{\circ} ; 45.441785^{\circ}, 20.457321^{\circ} ; 45.392375^{\circ}, 20.491025^{\circ}$; $45.341958^{\circ}, 20.573339^{\circ} ; 44.910732^{\circ}, 21.251252^{\circ} ; 45.861470^{\circ}$, $20.289596^{\circ} ; 45.841374^{\circ}, 20.326948^{\circ} ; 45.828110^{\circ}, 20.414018^{\circ}$; $45.477917^{\circ}, 20.437859^{\circ} ; 45.558680^{\circ}, 19.200801^{\circ} ; 45.535685^{\circ}$, $19.247582^{\circ} ; 45.352620^{\circ}, 19.623814^{\circ} ; 45.390899^{\circ}, 20.151332^{\circ}$.

Ceratophylletum demersi (Soó 1927) Hild 1956, Potametumnodosi Soó (1928) 1960, Segal 1964 and Myriophyllo-Potametum Soó 1934; whereas towards the canal banks, it is linked to emersed association stands Scirpo-Phragmitetum W. Koch 1926, Typhetum angustifoliae Pign. 1953, Glycerietum maximae Hueck 
1931, Sparganietum erecti Roll 1938 and Typhetum latifoliae G. Lang 1973 [30,31,33].

Amongst the analyzed water properties, the key factors that predetermine the Trapetum natantis phytocenosis differentiation into the aforementioned four groups are total and dissolved phosphorus, $\mathrm{BOD}_{5}, \mathrm{pH}$ and nitrate content (Tab. 2).

The water temperature was found not to be a significant factor in the phytocenosis differentiation in the studied ecosystem. Despite the evident temperature variation, no statistically significant differences were found (Tab. 2). Median values ranged from $23.4^{\circ} \mathrm{C}$ (II group) to $25.6^{\circ} \mathrm{C}$ (IV group). The greatest water temperature variation was noted in the canal sections where stands belonging to III group were developed (Fig. 2).

When water $\mathrm{pH}$ was analyzed, statistically significant differences between values pertaining to different localities were found for group II and IV $\left(P=0.0435^{\star}\right.$; Tab. 2$)$, which indicates that the stands including $C$. demersum develop in water characterized by significantly lower $\mathrm{pH}$ value $\left(M_{\mathrm{e}}=7.595\right)$, compared to the stands containing $H$. morsus-ranae $\left(M_{\mathrm{e}}=7.830\right.$; Fig. 2). The stands that include lemnids plants (III group) have shown the greatest tolerance even with the respect to variation in the water $\mathrm{pH}$ values (Fig. 2).

In the analyzed aquatic ecosystem, the total alkalinity, i.e. carbonate content, did not play a significant role in the differentiation of ass. Trapetum natantis into groups (Tab. 2). The localities in which the stands belonging to I group develop were characterized by the lowest carbonate content $\left(M_{\mathrm{e}}=159.00\right)$, whereas the water sampled at localities where IV group - the group most sensitive to the variation in this parameter - stands develop had the lowest carbonate content $\left(M_{\mathrm{e}}=225.00\right.$; Fig. 2).

In terms of chemical oxygen demand (COD), no statistically significant differences were found amongst the localities where the four stand groups develop (Tab. 2). The median varied from 6.05 (II group) to 7.10 (III group; Fig. 2). Group IV develops at localities characterized by the smallest variation in COD (Fig. 2).

Biological oxygen demand $\left(\mathrm{BOD}_{5}\right)$ in our study was found to be the factor that leads to the differentiation of the analyzed stand into groups. Statistically highly significant differences in $\mathrm{BOD}_{5}$ were found between localities where group I and II develop $\left(P=0.0002^{\star *}\right)$, as well as significant differences between localities where group I and II stands develop $\left(P=0.0374^{\star}\right)$, as shown in Tab. 2. In other words, the stand containing C. demersum (group II) develops in water with significantly lower $\mathrm{BOD}_{5}$ $\left(M_{\mathrm{e}}=1.825\right)$ compared to other analyzed localities (Fig. 2).
The ammonium ion water content measured at localities characterized by the development of a specific group did not vary significantly, and thus this parameter did not contribute to the differentiation of this phytocenosis (Tab. 2). The lowest values were measured in the areas where I group stands develop $\left(M_{\mathrm{e}}=0.24\right)$, and the highest in the areas occupied by II group stands $\left(M_{\mathrm{e}}=0.39\right)$.

The nitrate content analysis indicated that the development of the stands containing $H$. morsus-ranae (IV group) favor water richer in these compounds $\left(M_{\mathrm{e}}=1.98\right)$, compared to other groups and that it is also least tolerant of the significant variations in nitrate content (Fig. 2). In contrast to this group, higher nitrate content does not suit the development of stands dominated by T. natans. Statistically significant difference in the nitrate content was noted between the localities where these two groups formed $\left(P=0.0308^{\star}\right)$, as shown in Tab. 2 .

Nitrate content did not have significant effect on the development of some groups in the analyzed aquatic ecosystem (Tab. 2). Group I $(\min =0.007, \max =0.27)$ and group III $(\min =0.007$, $\max =0.351)$ were shown to be the most tolerant of the nitrate water content, whereas IV group was the most sensitive to the changes in this parameter (Fig. 2).

However, total phosphorus content proved to be a very important factor in the differentiation within Trapetum natantis. The stands containing $H$. morsus-ranae (IV group) develop in water more heavily loaded with phosphates $\left(M_{\mathrm{e}}=1.469\right)$ compared to the remaining three analyzed groups (Fig. 2). Statistically highly significant difference in the total phosphorus content was determined between the localities on which group I and IV are developed $\left(P=0.0023^{* *}\right)$, as well as those dominated by group II and IV $\left(P=0.0035^{\star *}\right.$; Tab. 2$)$.

The water dissolved phosphorus content analysis determined that the stands containing H. morsus-ranae (IV group) are typically found in water characterized by the higher dissolved phosphorus content $\left(M_{\mathrm{e}}=0.505\right)$, as shown in Fig. 2 . The stands dominated by T. natans (I group) develop in water containing far less dissolved phosphorus $\left(M_{\mathrm{e}}=0.119\right)$ compared to those containing $H$. morsus-ranae $\left(P=0.0304^{\star}\right.$; Tab. 2$)$.

\section{Discussion}

The association Trapetum natantis belongs to the floating therophytic community. Although it typically develops in

Tab. 2 Significance of differences in water properties between four groups of studied phytocoenoses.

\begin{tabular}{|c|c|c|c|c|c|c|}
\hline \multirow[b]{2}{*}{ Water properties } & \multicolumn{6}{|c|}{ Groups } \\
\hline & I-II & I-III & I-IV & II-III & II-IV & III-IV \\
\hline \multicolumn{7}{|l|}{ Temperature $\left({ }^{\circ} \mathrm{C}\right)$} \\
\hline $\mathrm{pH}$ & & & & & $0.0435^{*}$ & \\
\hline \multicolumn{7}{|l|}{ Total alkalinity $\left(\mathrm{mg} \mathrm{CaCo}_{3}\right)$} \\
\hline \multicolumn{7}{|l|}{$\mathrm{COD}-\mathrm{MnO}_{4}(\mathrm{mg} / \mathrm{l})$} \\
\hline $\mathrm{BOD}_{5}(\mathrm{mg} / \mathrm{l})$ & $0.0002^{* *}$ & & & & $0.0374^{\star}$ & \\
\hline \multicolumn{7}{|l|}{$\mathrm{NH}_{4}^{+}(\mathrm{mg} / \mathrm{l})$} \\
\hline $\mathrm{NO}_{3}^{-}(\mathrm{mg} / \mathrm{l})$ & & & $0.0308^{*}$ & & & \\
\hline \multicolumn{7}{|l|}{$\mathrm{NO}_{2}^{-}(\mathrm{mg} / \mathrm{l})$} \\
\hline $\mathrm{PO}_{4}^{3-}(\mathrm{mg} / \mathrm{l})$ & & & $0.0304^{*}$ & & & \\
\hline Total phosphorus (mg/l) & & & $0.0023^{* *}$ & & $0.0035^{\star *}$ & \\
\hline
\end{tabular}

Empty case - non-significant. ${ }^{\star} P<0.05{ }^{*}{ }^{\star} P<0.01$. 
Temperature $\left({ }^{\circ} \mathrm{C}\right)$
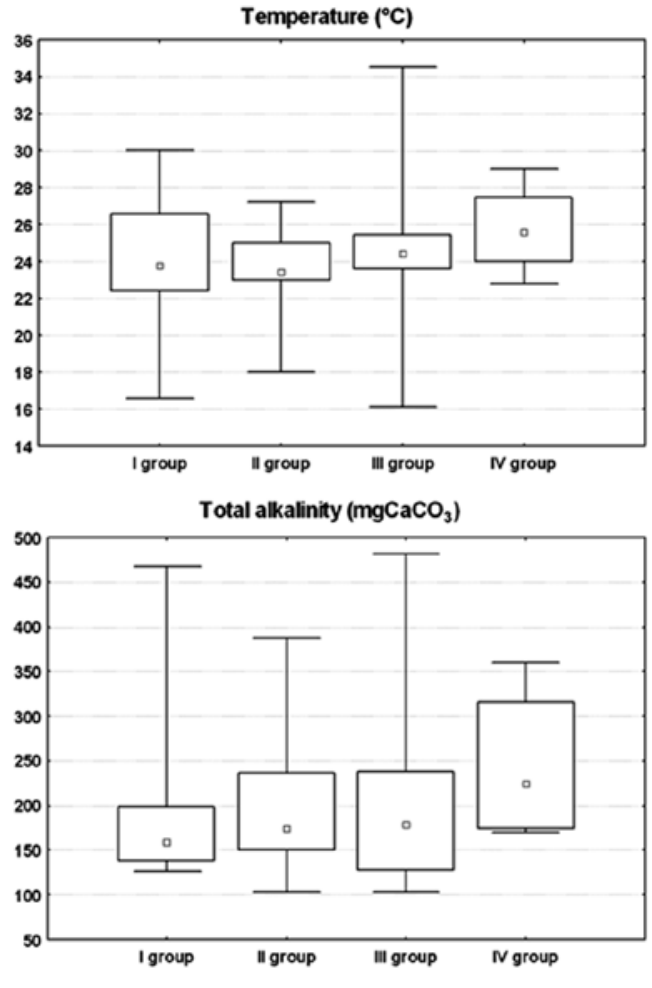

$\mathrm{BOD}_{5}(\mathrm{mg} / \mathrm{l})$

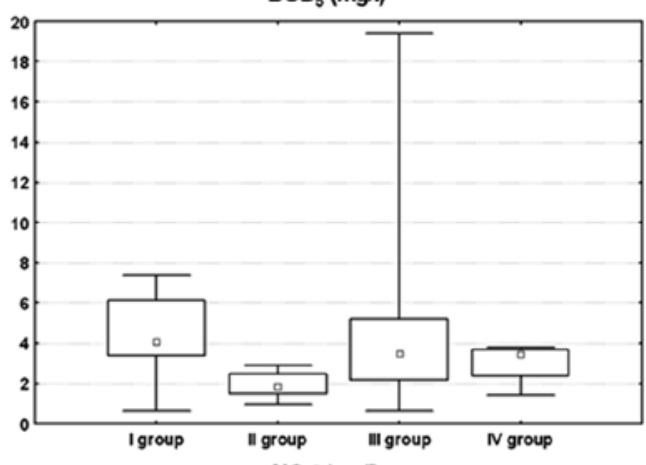

$\mathrm{NO}_{3}{ }^{-}(\mathrm{mg} / \mathrm{l})$
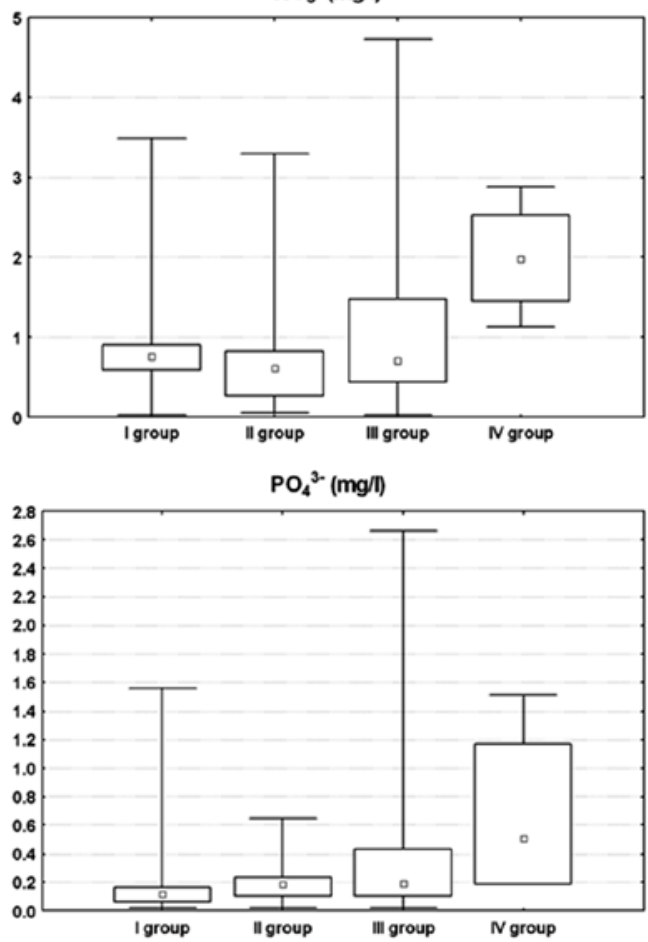

pH
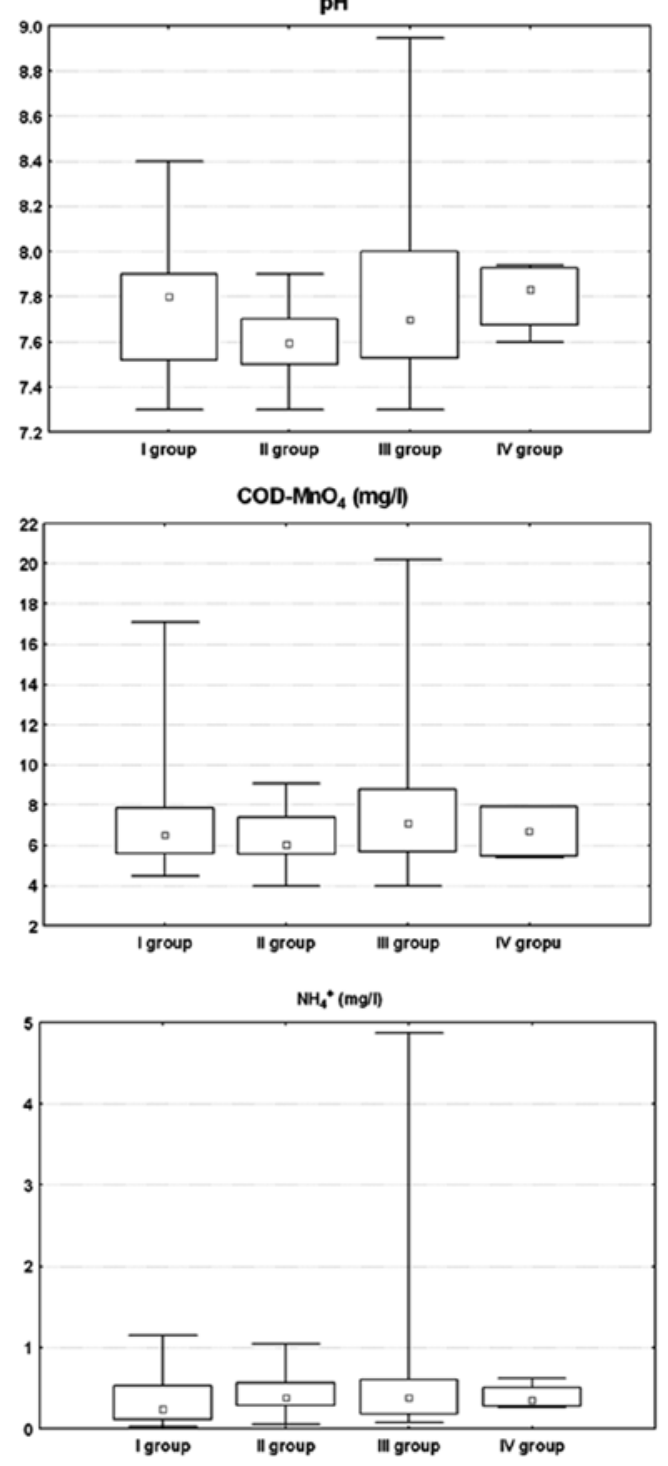

$\mathrm{NO}_{2}^{-}{ }^{-}(\mathrm{mg} / \mathrm{l})$

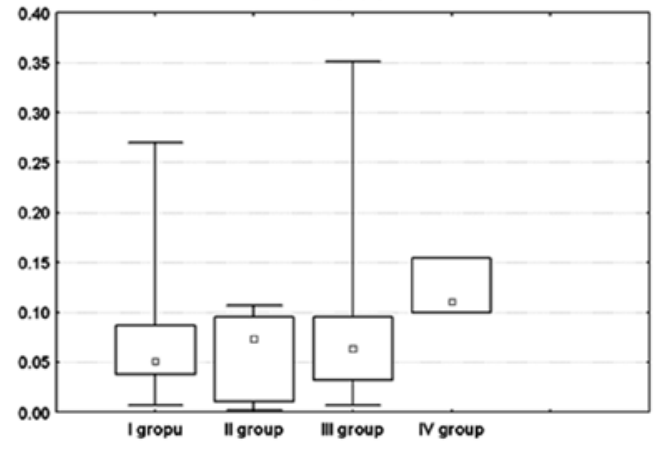

Total phosphorus (mg/l)

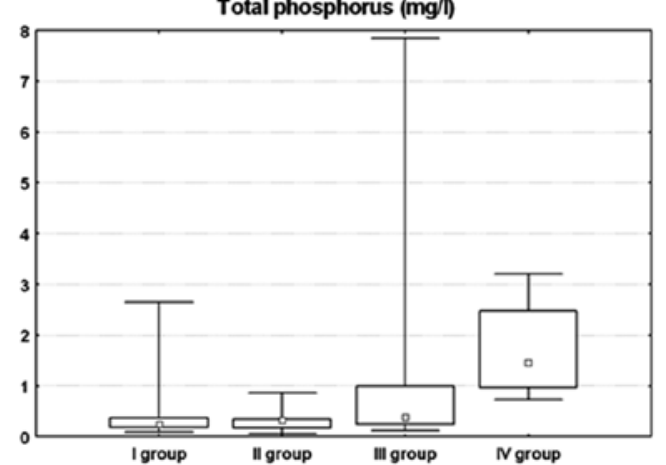

Fig. 2 Basic physico-chemical parameters of water quality in the stands of the four groups of ass. Trapetum natantis (I: the stands of Trapetum natantis; II: the stands of Trapetum natantis with Ceratophyllum demersum; III: the stands of Trapetum natantis with lemnoid plants; IV: the stands of Trapetum natantis with Hydrocharis morsus-ranae). Boxes show 25-75\% interquartile range of values and points show the medians. Whiskers show minimum and maximum values. 
stagnant waters, it is highly tolerant of frequent fluctuations in water levels [34,35], as was confirmed by the findings of this study, due to its significant development in the vicinity of barriers that cause frequent water level fluctuations.

Our results, as well as those reported in the pertinent literature $[3,36]$, confirm that ass. Trapetum natantis, is generally one of the most hemophilic aquatic phytocenoses, even though the water temperature differences where the samples of the studied groups were collected were not statistically significant.

In terms of its $\mathrm{pH}$, the T. natans association edificator is characterized differently by various authors: as neutrophilic $[34,37]$, or as very tolerant of the wide spectrum of $\mathrm{pH}$ values [1]. The findings of our study are in agreement with those reported by Kočić et al. [38] and Naylor [8], who determined that water with higher $\mathrm{pH}$ content is favorable for the ass. Trapetum natantis development. This parameter affected the differentiation within the studied association.

The total alcality, i.e. water carbonate content, did not play a significant role in the differentiation of the analyzed phytocenosis into groups $(\mathrm{min}=103.00, \max =481.60)$.

Despite high values of $\mathrm{COD}-\mathrm{KMnO}_{4}$ [37] and low values detected in other aquatic ecosystems where ass. Trapetum natantis is developed [39], our results indicate moderate presence of organic matter, and the variations in this parameter did not prove to be statistically significant. $\mathrm{BOD}_{5}$ indicates moderate to significant organic biodegradable matter presence (all median values are below $5 \mathrm{mg} / \mathrm{l}$ ). However, occasionally measured higher $\mathrm{BOD}_{5}$ values are most often due to organic pollution caused by release of untreated wastewater, industrial effluents and discharge from agricultural land $(\min =0.61, \max =19.40)$.

In terms of eutrophication, monitoring nutrient water content is essential. Hence, in our samples, we detected all forms of mineral nitrogen, amongst which nitrate form was predominant $(\min =0.03, \max =4.73)$. According to Hummel and Kivat [1], the growth of the T. natans population is linked to the increase in the nitrate levels, whereas our results indicate that it favors somewhat lower nitrate levels, which is in agreement with the view of Kočić et al. [38]. In terms of ammonium ion content, we can conclude that the water quality is compromised at the localities where most stands were found. The findings of our study indicate that the ammonia and nitrate levels did not affect the group differentiation within the analyzed association.

Total and dissolved phosphorus are very important parameters that led to the development of the individual groups within the described association. The results of the total phosphorus content analysis indicate that the eutrophication process is present in all canal segments where the stands of the analyzed phytocenosis are developed $(\min =0.052, \max =7.849)$. Total phosphorus content characterizes the water where group I, II and III are developed as eutrophic, and the water where IV group is developed as hypertrophic [39]. In addition to the $T$. natans phytocenosis edificators and subedificators of the groups C. demersum, L. minor, L. gibba, S. polyrrhiza, S. natans and $H$. morsus-ranae, other hydrophytes are developed in the stands, namely those that tolerate the high degree of trophicity well: P. pectinatus $[34,38,40]$, M. spicatum $[16,41,42]$, E. canadensis [36,42-45], etc. Thus, we can conclude that eutrophization, which occurs in the examined hydro-ecosystem as a result of human influence (intensive agricultural activity in the region through which the canal network is distributed, as well as urbanization, incomplete wastewater treatment that omits the additional removal of total phosphorus, usage of detergents that contain phosphorus, and release of wastewater from industrial sources) leads to the significant accumulation of nutrients, predominantly phosphorus, thus affecting the development and distribution of macrophytes. The consequences of the effects of water of compromised quality, which flows into Hs DTD from Romania, should not be underestimated either, as our findings indicate marked absence of ass. Trapetum natantis stands on the canal segments towards Romanian border (Fig. 1).

In the established, floristically rich, stands (28 species), based on the long-term phytocenological studies, four floristic and ecological groups were identified (Fig. 1, Tab. 1). Thus, in addition to defining ecological amplitudes and the optimal growth conditions for this phytocenosis, endangered in this region, the aim of this work was also to establish the extent to which the ecological amplitudes of the identified groups differed.

I GROUP. In most cases, the edificator T. natans is the most significant (Tab. 1). With 26 species, the stands belonging to this group are floristically the richest, and are characterized by the optimum growth at water depths of (0.3) 2-3 m.

The differentiation of this group is influenced by the high $\mathrm{BOD}_{5}$ values, which is the indicator of the higher presence of organic matter in the water $\left(M_{\mathrm{e}}=4.10\right)$. These stands prefer lower nitrate water content $\left(M_{\mathrm{e}}=0.76\right)$, as well as increased total phosphorus content that characterizes eutrophilic conditions [39]. These findings are in agreement with most published results $[2,8,34,35]$, even though some authors claim that the opposite is true, implying that these stands develop in water markedly poor in organic matter [46].

II GROUP. The stands with C. demersum L. (Tab. 1). Floristic content of this stand comprises 16 species, developed at water depths of 1.5-3 m.

The presence of these stands indicates significantly lower $\operatorname{BOD}_{5}\left(M_{\mathrm{e}}=1.825\right)$, which characterizes them as indicators of lower organic compound water content (values below $2 \mathrm{mg} / \mathrm{l}$ are typical of relatively clean water). Total phosphorus content characterizes conditions in these stands as eutrophic, which is in line with the findings of many other studies [16,35,42,43,46-50]. The key factor in the differentiation of these stands compared to other groups is the lower phosphorus level with a very narrow range of variation, even though Dimopoulos et al. [47] suggest that the significant development of $C$. demersum is only correlated with water depth.

III GROUP. The stands with lemnids plants (L. minor, L. gibba, S. polyrrhiza) and S. natans (Tab. 1) containing 12 hydrophytes. In addition to shallow waters close to the canal borders, fragments of these stands were also found in deeper waters. Based on the phosphorus content, the water conditions in this group are characterized as eutrophic [39], as confirmed by the findings of other studies $[40,42,51]$. Even though the difference is not statistically significant, the ammonium ion content is notable, as it reaches the value of $\max =4.87$ (most values exceed $0.3 \mathrm{mg} / \mathrm{l}$ ), leading to the conclusion that the water in which these stands develop is of compromised quality.

IV GROUP. The stands with $H$. morsus-ranae (Tab. 1 ). This group is floristically the poorest, with only 11 hydrophytes, and the stands are formed at water depths of $0.5-1.5 \mathrm{~m}$.

In terms of their chemical characteristics, the stands in this group are most clearly differentiated compared to others. These stands favor conditions characterized by somewhat higher temperature compared to other groups, which is expected, given that high temperature is the key factor in determining the size of the H. morsus-ranae population [52]. Somewhat higher values of carbonates in water are in agreement with the fact that this subedificator prefers water rich in carbonates 
[51]. Nitrate water content is also higher than that measured at localities where other groups are developed $\left(M_{\mathrm{e}}=1.98\right)$. As stands containing $H$. morsus-ranae are developed in water rich in phosphates, total phosphorus content characterizes these conditions as hypertrophic [39]. The conditions reported in the literature as optimal for development of $H$. morsus-ranae can be mesotrophic $[53,54]$, eutrophic $[35,36,40,43,55]$ and hypertrophic $[42,51,56]$, which is in line with our findings.

In addition to the analyzed chemical water parameters, hydromorphological waterway characteristics also significantly affect the macrophyte composition, the number of species and their distribution within the association [16,35,38,57-60]. In Hs DTD, the variable canal width and depth, flow rate, water traffic intensity in certain sections, the mode of water supply (from Danube or indirectly through other canals), the characteristics of the canal banks, presence of 23 sluices, and artificially modified water levels (changing several times during the vegetative period), contribute to the varied conditions for the development of vegetation, which is certainly one of the reasons behind the floristic and ecological differentiation of ass. Trapetum natantis. Moreover, given the canal length $(930 \mathrm{~km})$ and the varied age of its segments (50-200 years), research has shown that the macrophytic vegetation found in this ecosystem is in different developmental stages, i.e. forms a successive series.

Generally, the expansion of ass. Trapetum natantis stands in the northern parts of Serbia is, amongst other factors, affected by the anthropogenically expedited eutrophication. Whilst successions from oligotrophic, mesotrophic to eutrophic or dystrophic aquatic ecosystems last for thousands of years and lead to valuable complexes of phytocenoses, the effects of anthropogenically-induced eutrophications are evident after only several decades $[1,42]$. Significant quantities of biogenic matter introduced into the ecosystem in incremental steps lead to the disappearance of species with narrow ecological amplitudes and the expansion of eurivalent species. Thus, macrophytic vegetation rapidly responds to the changes by increasing production and biomass, followed by reduction in biodiversity [61-65]. In particular, T. natans, which develops most optimally in nutrient rich waters $[2,8,34,35]$, responds to the newly established conditions by significantly expanding its development. The studied T. natans tolerance of the water level and flow rate fluctuations $[34,35]$ indicates that this species favors hydromeliorative facilities where these changes are intensive. The effects of the changes in the climatic conditions and the effects of global warming should not be underestimated, as these too affect the proliferation of thermophilic stands of ass. Trapetum natantis.

The "European water framework directive" (WFD), with the aim of reaching the goals of the "good ecological status" concept, in addition to chemical, expects the ecological assessment of the waterway as well, in terms of various biological elements, one of which is macrophytic associations [66]. The results of the ecological assessments of the waterway that use macrophytes as indicators cannot be generalized, as they are specific to geographical locations where the study has been conducted, as well as the waterway hydromorphology and the method of study $[5,58,67-71]$. That is why it is essential to standardize and streamline the study procedures in order to produce national macrophyte map and understand the complex interactions between macrophytes and the environment [72]. Our results are particularly important, as they might shed some light on the mechanisms that lead to species endangerment, disappearance of some plant species in one region, its expansive growth in another, or even invasive proliferation in some remote regions.

\section{Acknowledgments}

This study was supported by the public water management company Vode Vojvodine, Novi Sad (Serbia). The authors would like to acknowledge to two anonymous reviewers for constructive and helpful comments.

\section{Authors' contributions}

The following declarations about authors' contributions to the research have been made: wrote the paper: DD; field research: DD, BLM, LN; phytosociological analyses: BLM, DD; chemical analysis: LN, BLM; preparation of distribution map: BLM; statistical analysis: BLM.

\section{References}

1. Hummel M, Kiviat E. Review of world literature on water chestnut with implications for management in North America. J Aquat Plant Manag. 2004;42:17-28.

2. Pemberton RW. Water chestnut. In: Van Driesche RG, Blossey B, Hoddle M, Lyon S, Reardon R, editors. Biological control of invasive plants in the eastern United States. Morgantown WV: USDA, Forest Service, FHTET; 2002. p. 33-40.

3. Olszewski T, Markowski T. Trapa natans L. s. l. as extinct in the 19th century component of Gdańsk Pomerania flora. In: Olszewski T, Afranowicz R, Bociąg K, editors. Contemporary trends of botanical research - on Professor Hanna Piotrowska 80th birthday anniversary. 2007. p. 153-156. (Acta Bot Cassub; vol 6).

4. The IUCN red list of threatened species. Version 2012.2 [Internet]. [cited 2012 Oct 22]; Available from: http://www.iucnredlist.org

5. Službeni list RCG br. 76/06, od 12. decembra 2006. godine. Riješenje o stavljanju pod zaštitu pojedinih biljnih i životinjskih vrsta [Internet]. [cited 2012 Oct 8]. Available from: http://www.sluzbenilist.me/PravniAktDetalji. aspx?tag=\%7B43FC514F-EA49-4B25-82C8-FAE638FECB23\%7D

6. Ciocârlan V. Vascular flora of the Danube Delta. Analele Stiintifice Ale Univ. Al Cuza Iasi. 2011;57(1):41-64.

7. Les DH, Mehrhoff LJ. Introduction of nonindigenous aquatic vascular plants in southern New England: a historical perspective. Biol Invasions. 1999;1(2-3):281-300. http://dx.doi.org/10.1023/A:1010086232220

8. Naylor M. Water chestnut in the Chesapeake Bay watershed: a regional management plan. Baltimore MD: Maryland Department of Natural Resources; 2003.

9. Alternative farming systems information center [Internet]. Usda Natl. Agric. Libr. 2011 [cited 2011 Dec 12]; Available from: http://www.nal. usda.gov/afsic/pubs/terms

10. Pyšek P, Richardson DM, Rejmánek M, Webster GL, Williamson $M$, Kirschner J. Alien plants in checklists and floras: towards better communication between taxonomists and ecologists. Taxon. 2004;53(1):131. http://dx.doi.org/10.2307/4135498

11. Chambers PA, Lacoul P, Murphy KJ, Thomaz SM. Global diversity of aquatic macrophytes in freshwater. Hydrobiologia. 2008;595:9-26. http:// dx.doi.org/10.1007/s10750-007-9154-6

12. Thiébaut $\mathrm{G}$. Invasion success of non-indigenous aquatic and semi-aquatic plants in their native and introduced ranges. A comparison between their invasiveness in North America and in France. Biol Invasions. 2006;9(1):1-12. http://dx.doi.org/10.1007/s10530-006-9000-1 
13. Wetzel RG. Invasive plants: the process within wetland ecosystems. In: Inderjit S, Drake AJ, editors. Invasive plants: ecological and agricultural aspects. Basel: Birkhäuser Verlag; 2005. p. 115-127.

14. Bernez I, Aguiar F, Violle C, Ferreira T. Invasive river plants from Portuguese floodplains: what can species attributes tell us? Hydrobiologia. 2006;570(1):3-9. http://dx.doi.org/10.1007/s10750-006-0155-7

15. Vuković N, Bernardić A, Nikolić T, Hršak V, Plazibat M, Jelaska S. Analysis and distributional patterns of the invasive flora in a protected mountain area - a case study of Medvednica Nature park (Croatia). Acta Soc Bot Pol. 2010;79(4):285-294.

16. Lacoul P, Freedman B. Environmental influences on aquatic plants in freshwater ecosystems. Environ. Rev. 2006;14(2):89-136. http://dx.doi. org/10.1139/a06-001

17. Carpenter SR, Lodge DM. Effects of submersed macrophytes on ecosystem processes. Aquat Bot. 1986;26:341-370. http://dx.doi. org/10.1016/0304-3770(86)90031-8

18. Chase JM, Knight TM. Effects of eutrophication and snails on Eurasian watermilfoil (Myriophyllum spicatum) invasion. Biol Invasions. 2006;8(8):1643-1649. http://dx.doi.org/10.1007/s10530-005-3933-7

19. Braun-Blanquet J. Pflanzensoziologie. 3rd ed. Wien: Springer; 1964.

20. Josifović M, editor. Flora of SR Serbia. Beograd: SANU; 1970. (vol 1-9).

21. Sarić M, editor. Flora of SR Serbia. Beograd: SANU; 1986. (vol 10).

22. Tutin TG, Heywood VH, Burges NA, Valentine DH, Walters SM, Webb DA, editors. Flora Europaea. Cambridge: Cambridge University Press; 1964. (vol 1).

23. Tutin TG, Heywood VH, Burges NA, Moore DM, Valentine DH, Walters SM, et al., editors. Flora Europaea. Cambridge: Cambridge University Press; 1968. (vol 2-5).

24. Felföldy L. Visugyi hidrobiologia. Budapest: 18-Kotet-Hinar haterarazo Korniezetveldelmi es Teruletfejlestesi Miniszterium; 1990.

25. Jávorka S, Csapody V. Iconographie der Flora des Südostlichen Mitteleuropa. Budapest: Akadémiai Kiadó; 1975.

26. Hennekens SM, Schaminée JHJ. TURBOVEG, a comprehensive data base management system for vegetation data. J Veg Sci. 2001;12(4):589-591. http://dx.doi.org/10.2307/3237010

27. Tichý L. JUICE, software for vegetation classification. J Veg Sci. 2002;13(3):451-453. http://dx.doi.org/10.1111/j.1654-1103.2002.tb02069.x

28. APHA, AWWA, WPCF. Standard methods for examination of water and wastewater. 17th ed. Washington DC: APHA; 1995.

29. STATISTICA 7.0. StatSoft; 2004.

30. Lazić D. Vaskular flora and vegetation in the MCH of HS DTD on the territory of Bačka - current situation and management [PhD thesis]. Novi Sad: University of Novi Sad; 2006.

31. Ljevnaić-Mašić B. Hidrophytes in Main Canal Network of DTD Hydrosystem on the territory of Banat [PhD thesis]. Novi Sad: University of Novi Sad; 2010.

32. Blaženčić J. The effect on the water chestnut (Trapa L.) survival in associations with the white and yellow water lily [Nymphaea alba L. and Nuphar lutea (L.) Sm. in Sibth. et Sm.]. In: 8th symposium on the flora of Southeastern Serbia and neighbouring regions. Niš: Faculty of Natural Sciences and Mathematics; 2005. p. 68.

33. Džigurski $D$, Knežević $A$, Stojanović $S$, Nikolić $L$, Ljevnaić-Mašić $B$. The vegetation of canal Novi Sad-Savino Selo. Thaiszia. 2010;20:137-145.

34. Hrivnák R. Aquatic plant communities in the catchment area of the Ipel' river in Slovakai and Hungary. Part II. Class Potametea. Thaiszia. 2002;12:137-160.

35. Schneider E. Aquatic macrophytes in the Danube Delta - indicators for water quality and habitat parameters. Stud Univ Babes-bolyai Biol. 2009;54(1):21-31.

36. Coldea G, Sanda V, Popescu A, Ştefan N, editors. Les associations végétales de Roumanie. Cluj: Presses Universitaires de Cluj; 1997. (vol 1).

37. Szankowski M, Kłosowski S. Habitat conditions of nymphaeid associations in Poland. Hydrobiologia. 1999;415:177-185. http://dx.doi.
org/10.1023/A:1003837520267

38. Kočić A, Hengl T, Horvatić J. Water nutrient concentrations in channels in relation to occurrence of aquatic plants: a case study in eastern Croatia. Hydrobiologia. 2008;603(1):253-266. http://dx.doi.org/10.1007/ s10750-007-9276-x

39. OECD. Eutrophication of waters: monitoring, assessment and control. Paris: Organisation for Economic Co-operation and Development; 1982.

40. Staniszewski R. Estimation of river trophy in the Kujawskie Lakeland using mean trophic rank and chemical index of trophy. Rocz Ar Pozn Bot. 2001;4:165-173.

41. Madsen JD. Predicting invasion success of Eurasian watermilfoil. J Aquat Plant Manag. 1998;36:28-32.

42. Balevičienė J, Balevičius A. Qualitative and quantitative parameters of phytocenoses in Lithuanian lakes of different trophic state. Ekologija. 2006;2:34-43.

43. Nurminen L. Macrophyte species composition reflecting water quality changes in adjacent water bodies of lake Hiidenvesi, SW Finland. Ann Bot Fenn. 2003;40:199-208.

44. Barrat-Segretain MH, Elger A. Experiments on growth interactions between two invasive macrophyte species. J Veg Sci. 2004;15(1):109-114. http:// dx.doi.org/10.1111/j.1654-1103.2004.tb02243.x

45. Kuhar U, Germ M, Gaberščik A. Habitat characteristics of an alien species Elodea canadensis in Slovenian watercourses. Hydrobiologia. 2010;656(1):205-212. http://dx.doi.org/10.1007/s10750-010-0438-x

46. Lukács BA, Dévai G, Tóthmérész B. Aquatic macrophytes as bioindicators of water chemistry in nutrient rich backwaters along the Upper-Tisza river (in Hungary). Phytocoenologia. 2009;39(3):287-293. http://dx.doi.org/10 .1127/0340\&U8211;269X/2009/0039\&U8211;0287

47. Dimopoulos P, Sýkora K, Gilissen C, Wiecherink D, Georgiadis T. Vegetation ecology of Kalodiki Fen (NW Greece). Biologia (Bratisl). 2005;60(1):69-82.

48. Sugier P, Lorens B, Chmiel S, Turczyński M. The influence of Ceratophyllum demersum L. and Stratiotes aloides L. on richness and diversity of aquatic vegetation in the lakes of mid-eastern Poland. Hydrobiologia. 2010;656(1):43-53. http://dx.doi.org/10.1007/s10750-010-0433-2

49. Nikolić L, Pajević S, Ljevnaić B. Primary production dynamics of dominant hydrophytes in Lake Provala (Serbia). Cent Eur J Biol. 2009;4(2):250-257. http://dx.doi.org/10.2478/s11535-009-0013-5

50. Nikolić L, Čobanović K, Lazić D. Nymphoides peltata (Gmel.) Kuntze, Myriophyllum spicatum L. and Ceratophyllum demersum L. biomass dynamics in Lake Provala (the Vojvodina Province, Serbia). Cent Eur J Biol. 2007;2(1):156-168. http://dx.doi.org/10.2478/s11535-007-0003-4

51. Sýkora KV. Field guide Dutch plant communities. Species composition and ecology. 2006.

52. Zhu B, Eppers ME, Rudstam LG. Predicting invasion of European frogbit in the Finger Lakes of New York. J Aquat Plant Manag. 2008;46(46):186-189.

53. Cook CD, Lüönd R. A revision of the genus Hydrocharis (Hydrocharitaceae). Aquat Bot. 1982;14:177-204. http://dx.doi. org/10.1016/0304-3770(82)90097-3

54. Catling PM, Mitrow G, Haber E, Posluszny U, Charlton WA. The biology of Canadian weeds. 124. Hydrocharis morsus-ranae L. Can J Plant Sci. 2003;83(4):1001-1016. http://dx.doi.org/10.4141/P02-033

55. Catling PM, Dore WG. Status and identification of Hydrocharis morsusranae and Limnobium spongia (Hydrocharitaceae) in northeastern North America. Rhodora. 1982;84:523-545.

56. Klavins M, Rodinov V, Druvietis I. Aquatic chemistry and humic substances in bog lakes in Latvia. Boreal Env Res. 2002;8:113-123.

57. Hrivnák R, Ot’ahel’ová $H$, Valachovič M, Palove-Balang P, Kubinská A. Effect of environmental variables on the aquatic macrophyte composition pattern in streams: a case study from Slovakia. Fundam Appl Limnol. 2010;177(2):115-124. http://dx.doi.org/10.1127/1863-9135/2010/0177-0115

58. Bernez I, Daniel H, Haury J, Ferreira MT. Combined effects of environmental factors and regulation on macrophyte vegetation along three 
rivers in western France. River Res Appl. 2004;20(1):43-59. http://dx.doi. org/10.1002/rra.718

59. Madsen JD, Stewart RM, Getsinger K, Johnson RL, Wersal RM. Aquatic plant communities in Waneta Lake and Lamoka Lake, New York. Northeast Nat. 2008;15:97-110.

60. O'Hare MT, Baattrup-Pedersen A, Nijboer R, Szoszkiewicz K, Ferreira T. Macrophyte communities of European streams with altered physical habitat. Hydrobiologia. 2006;566(1):197-210. http://dx.doi.org/10.1007/ s10750-006-0095-2

61. Sender J. Changes in structure of macrophyte communities in the chosen lakes of Łęczna-Włodawa Lake District. Ecohydrol Hydrobiol. 2009;9(24):237-245. http://dx.doi.org/10.2478/v10104-010-0018-8

62. Jabłońska E, Kłosowski S. Ecology of rare water plant communities in lakes of north-eastern Poland. Acta Soc Bot Pol. 2012;81(1):3-9. http:// dx.doi.org/10.5586/aspb.2012.006

63. Hrivnák R, Ot’ahel’ová H, Valachovič M. The relationship between macrophyte vegetation and habitat factors along a middle-size European river. Pol J Ecol. 2007;55:717-729.

64. Kremser U, Schnug E. Impact of fertilizers on aquatic ecosystems and protection of water bodies from mineral nutrients. Landbauforsch. Völkenrode. 2002;2(52):81-90.

65. Schaumburg J, Schranz C, Foerster J, Gutowski A, Hofmann G, Meilinger P, et al. Ecological classification of macrophytes and phytobenthos for rivers in Germany according to the water framework directive. Limnologica.
2004;34(4):283-301. http://dx.doi.org/10.1016/S0075-9511(04)80002-1

66. European Commission. Directive 2000/60/EC of the European Parliament and of the Council of 23rd October 2000: establishing a framework for Community action in the field of water policy. Off J Eur Communities. 2000;327:1-72.

67. Hrivnák R, Otahel’ová $\mathrm{H}$, Jarolímek I. Diversity of aquatic macrophytes in relation to environmental factors in the Slatina river (Slovakia). Biologia (Bratisl). 2006;61(4):413-419. http://dx.doi.org/10.2478/s11756-006-0071-3

68. Ferreira T, Aguiar F. Riparian and aquatic vegetation in Mediterranean-type streams (western Iberia). Limnetica. 2006;25(1):411-424.

69. Lewin I, Szoszkiewicz K. Drivers of macrophyte development in rivers in an agricultural area: indicative species reactions. Cent Eur J Biol. 2012;7(4):731-740. http://dx.doi.org/10.2478/s11535-012-0053-0

70. Fabris M, Ghetti PF. Application and development of river quality bioindication methods based on macrophytes. In: 4th ECRR conference on river restoration Italy, Venice S. Servolo Island 16-21 June 2008. Venice: ECRR; 2008.

71. Ot’ahel’ová H, Hrivnák R, Valachovič M, Janauer G. Temporal changes of aquatic macrophyres vegetation in a lowland groundwater feed eutrophic course (Klátovske Rameno, Slovakai). Acta Soc Bot Pol. 2007;76(2):141-150.

72. Birk S, Willby N. Towards harmonization of ecological quality classification: establishing common grounds in European macrophyte assessment for rivers. Hydrobiologia. 2010;652(1):149-163. http://dx.doi.org/10.1007/ s10750-010-0327-3 